\title{
Fertility Recovery in Cows with Clinical Endometritis
}

\author{
Aleksandr Semivolos*, Anastasia Bryukhanova, and Ivan Pankov \\ Saratov State Agrarian University named after N.I. Vavilov, 1 Teatralnaya Ploshchad, Saratov, \\ 410012, Russia
}

\begin{abstract}
The article presents the materials of microbiological studies of the contents of the uterus of cows with acute catarrhal-purulent form of postpartum endometritis. Studies have shown that the microflora was represented by Proteus vulgaris, Escherichia coli, Staphylococcus aureus, Streptococcus faecium, Citrobacter freundii, Streptococcus pyogenes. The antibacterial activity of microflora to the drugs Enroflor ${ }^{\circledR}$, Geomicini ${ }^{\circledR}$ F and Mitrec ${ }^{\circledR}$ was studied. The results of use of drugs for the clinical recovery of animals, the restoration of sexual cyclicity in cows were analyzed. The features of fertilization of cows after intrauterine use of various drugs for sexual cycles and for the entire duration of the experiment were studied. It was found that the highest therapeutic efficiency in the treatment of cows with acute catarrhal - purulent form of postpartum endometritis is provided by drug Mitrec ${ }^{\circledR}$.
\end{abstract}

\section{Introduction}

Diseases of the reproductive organs in cows are a significant factor in reducing intensive reproduction in dairy cattle breeding. Very often after calving, acute postpartum endometritis occurs, which reduce milk production, milk quality, often lead to subfertility, premature culling and even death of sick animals [1].

According to many authors, acute postpartum clinical endometritis is recorded in 10$20 \%$ of cows. So after a study in Canada of 1865 cows, clinical endometritis was found in $16.9 \%$ of animals [2].

In Russia, postpartum acute endometritis is found at various farms in 17.7-36.1\%; chronic $-10.9-14.0 \%$; subclinical $-11.1-20.0 \%$ of lactating cows $[3,4,5]$.

The growing dynamics of an increase in the spread of endometritis in cows began to attract scientists to the study of the etiology of the occurrence and the development of methods for treating animals with this pathology of the uterus.

Some researchers believe that a decreased contractile function of the uterine muscles leads to a slowdown in uterine involution, causing dystocia, retention of the placenta, endometritis and metritis, and for the diagnosis of endometritis, they recommend using transrectal palpation or transrectal ultrasonography $7[6,7]$.

The factors that delay the involution of the uterus are very important, since the completion of the involution is associated with fertility. It is believed that it takes 3-4 weeks

\footnotetext{
${ }^{*}$ Corresponding author: semivolos-am@yandex.ru
} 
for the endometrium to completely restore the normal architecture of the endometrial tissue and restore the normal sexual cycle in cows [8].

Some experts point out that not only acute postpartum endometritis exclude the manifestation of sexual cyclicity, the onset of pregnancy in cows after insemination, but the inflammatory process often passes from the cervix to the uterus and oviducts, completely excluding the possibility of female fertilization [9].

Whereas [10] believe that one of the factors affecting the delay in uterine involution and occurrence of endometritis may be an increased LH content and low FSH level, which does not allow the development of a dominant follicle in the ovary.

Despite a wide variety of factors influencing the occurrence of endometritis, almost all researchers recognize a bacterial infection in the uterus as the leading factor [11-13].

Development of microflora in the uterine cavity is associated with endometrial injuries during childbirth and obstetrics [14].

A number of authors consider the presence of not only E. coli, T. pyogenes as the main microflora in various forms of endometritis, but also Bacteroidetes and Firmicutes, bacteria Trueperella, Fusobacteria and Prevotella [15].

The entry of microflora into the uterus from the vagina and cervix is not excluded [16].

Some authors pay great importance to various fungi within development of endometritis $[17,18,19]$.

Other researchers [20] argue that more than 100 species of fungi can be an etiological factor in occurrence of diseases of the reproductive organs of an inflammatory nature in animals and humans.

The authors state that the most common fungi in the uterus of cows with endometritis are Aspergillis fumigates and Penicillium. Such fungi were found in acute forms of postpartum endometritis in $17.98 \%$ of sick animals.

An interesting assumption is made by $[21,22]$. They disagree with the traditional belief that the uterus is sterile after the postpartum period. There is evidence from studies using fluorescent probes for bacteria that indicate the presence of rare bacteria in the uterus: Trueperella, Fusobacteria and Prevotella even during pregnancy, but such bacteria are not found in all animals and not in large quantities.

It shall be borne in mind that a long course of the inflammatory process in the uterus can lead to immunological disorders in the body of animals [23]. Dairy cows exhibit metabolic stress postpartum with decreased nutrient concentrations and metabolic disturbances. Deficiency of essential nutrients reduces the therapeutic efficacy of acute postpartum endometritis and often contributes to development of chronic forms of endometritis [24, 25, 26, 27].

It has been established that bacterial infections in the uterus with endometritis can disrupt the function of the hypothalamic-pituitary system, reduce the secretion of gonadotropins. Wherein, the quantity and quality of oocytes sharply decreases. The growth of vesicular follicles stops or their massive atresia sets in [1].

Many methods have been offered for treatment of endometritis in cows.

The general principle of treatment for clinical endometritis is to reduce the number of pathogenic bacteria, increase uterine defenses and endometrial repair mechanisms to ensure fertility in females. In this case, preference is given to etiotropic therapy [30].

Many strains are most sensitive to drugs such as norfloxacin $(98.1 \%)$, marbofloxacin $(95.8 \%)$, gentamicin $(88 \%)$, ceftiofur hydrochloride $-73.1 \%$. Use of such drugs helped to improve the clinical signs of endometritis in cows. Whereas T. pyogenes and E. coli were resistant to oxytetracycline (63.7 and $31 \%$ ). This is indicated by papers of [31].

In addition, this method of treating endometritis allows the corpus luteum of the ovary to be involved faster after calving. 
Some authors recommend using a single application of PGF 2a, but according to their data, the therapeutic efficacy of PGF $2 \alpha$ for the treatment of cows with clinical endometritis is not very high and is comparable to the efficacy of a more affordable alternative therapy: Lugol's solution, polyvinylpyrrolidone-iodine solution [32].

If [33] also give preference to intrauterine administration of antibiotics for treatment of acute postpartum endometritis, paying attention to the need to control their content in milk, then [34] recommend the use of systemic antibacterial treatment of clinical endometritis in dairy cows with ceftiofur or two doses of cloprostenol with a 14-day interval.

Many veterinarians widely use the introduction of antiseptics into the uterine cavity with endometritis. However, some scientists doubt the advisability of intrauterine administration of antimicrobial antiseptics to cows due to possible irritation of the endometrium [35].

In experiments of $[36,37]$, positive results were obtained in the treatment of acute postpartum endometritis in cows after intrauterine administration of ozone.

Preliminary studies [38] have obtained good results in the treatment of cows with postpartum endometritis by intrauterine administration of hyperimmune serum.

Some authors directly indicate that, in comparison with systemic treatment of animals, it is better to use intrauterine administration of antimicrobial drugs, since a high concentration of the drug is achieved faster in the area of endometrial inflammation and with little penetration into the deeper layers of the uterine wall and other genital organs [39].

In recent years, instead of the well-known antimicrobial drugs for cows with clinical endometritis, a $50 \%$ dextrose 40 solution or a proteolytic enzyme containing solutions of trypsin, chymotrypsin, and papain has been used as alternative drugs [41]. However, such claims require solid evidence in a larger livestock population.

Despite the great attention of scientists to development and improvement of various methods and technologies for treating animals with various forms of endometritis, this problem has not yet been resolved.

Therefore, the purpose of our study was to study the comparative therapeutic efficacy of various methods of treating cows with postpartum acute catarrhal-purulent endometritis, including the new Russian drug Miterc.

\section{Methods}

The material for the study was Simmental cows with acute postpartum catarrhal-purulent endometritis

The diagnosis of diseases of the reproductive organs in cows was made based on the analysis of data from echographic studies.

The contents of the uterus for microbiological studies were taken from the cervix by hand from cows with an acute catarrhal-purulent form of endometritis. Microbiological studies for the isolation of isolates were carried out according to generally accepted methods. The species belonging of microorganisms was established, guided by the "Identifier of bacteria", and fungi - "Atlas of fungi pathogenic for farm animals and birds". The identification was carried out taking into account the morphological, cultural and biochemical properties of microorganisms according to generally accepted methods.

Determination of the sensitivity of the isolated microorganisms to drugs: "Enroflon", "Geomicini ${ }^{\circledR} F "$ and "Mitrec" was carried out on AGV medium by diffusion into agar discs with antibiotics.

The study of the effectiveness of various drugs in acute postpartum catarrhal-purulent endometritis was carried out on cows, which were randomized into three groups of 12 animals each 
The diagnosis of postpartum, acute catarrhal-purulent endometritis was established by clinical echographic methods.

The cows of the first experimental group were injected intrauterinely, 1-2 tablets, with the foaming agent Enroflor ${ }^{\circledR}$ until the cervical canal was closed. The active ingredients are enrofloxacin and colistin sulfate. It is an antibacterial drug with a broad spectrum of action on the microflora of the uterus with endometritis.

The cows of the second experimental group were taken 1-2 tablets of the Geomicini ${ }^{\circledR} \mathrm{F}$ preparation into the uterine cavity with an interval of 24 hours until the cervical canal was closed. The active ingredient of the preparation is oxytetracycline dihydrate with a wide spectrum of bacteriostatic activity against many pathogenic microorganisms. In addition, Geomicini ${ }^{\circledR F}$ has foaming properties.

To the animals of the third experimental group a new Russian drug Mitrec ${ }^{\circledR}$ were injected intrauterinely in the form of a suspension from a syringe $(19 \mathrm{ml})$ with an interval of 24 hours until the cervical canal was closed. Cefapirin, which is part of the drug, has a wide spectrum of bactericidal action on the microflora of the uterus of cows with endometritis.

The clinical recovery of cows of different groups was evaluated in the first 10 days of the experiment, and observations of the animals were carried out for 90 days: the manifestation of sexual cyclicity, the results of fertilization, the number of doses of drugs used were taken into account.

\section{Results}

The microbiome of the contents of the uterus of cows with acute purulent-catarrhal endometritis was represented by Proteus vulgaris, Escherichia coli, Staphylococcus aureus, Streptococcus faecium, Citrobacter freundii, Streptococcus pyogenes. The opportunistic microbiome was dominant.

The bactericidal properties of various drugs, as shown by microbiological studies, had specific features (Tables 1, 2 and 3, Fig. 1).

So, the zone of growth retardation of the microbiome isolate to geomycin turned out to be insensitive for - Staphylococcus pyogenes $(19.09 \pm 0.66 \mathrm{~mm})$; moderately sensitive for microbiome isolates - Proteus vulgaris, $(28.22 \pm 2.37 \mathrm{~mm})$, sensitive for microbiome isolates - Proteus vulgaris $(23.27 \pm 1.85 \mathrm{~mm})$, Staphylococcus aureus $(21.62 \pm 1.76 \mathrm{~mm})$, Streptococcus faecium $(22.83 \pm 1.25 \mathrm{~mm})$, Escherichia coli $(26.11 \pm 2.11 \mathrm{~mm})$, Citrobacter freundii $(27.21 \pm 2.12 \mathrm{~mm})$. The isolates of Streptococcus faecium, Citrobacter freundii, and Escherichia coli had the maximum (100\%) sensitivity to geomycin.

The highest antibacterial activity of enroflon was against Proteus vulgaris $-21.15 \pm$ $0.62 \mathrm{~mm}$. When testing 12 isolates of Staphylococcus aureus, only in 7 cases the zone of inhibition of microbiome growth was $23.17 \pm 1.79 \mathrm{~mm}$, where, out of 4 isolates of Streptococcus faecium - 3 were sensitive and had a zone of growth inhibition of $25.16 \pm$ $1.36 \mathrm{~mm}$.

Of the 18 isolates of Escherichia coli, only 9 were susceptible to this drug. The growth inhibition zone of Staphylococcus pyogenes was $17.22 \pm 0.78 \mathrm{~mm}$.

It shall only be noted that isolates of Proteus vulgaris, Streptococcus faecium, Citrobacter freundii strains had $100 \%$ sensitivity to enroflon. 
Table 1. Results of the sensitivity of the microbiome of the contents of the uterus in acute purulentcatarrhal endometritis of cows to the drug geomycin.

\begin{tabular}{|c|l|c|c|c|c|}
\hline $\begin{array}{c}\text { Ser. } \\
\text { No. }\end{array}$ & \multicolumn{1}{|c|}{ Microbiome } & $\begin{array}{c}\text { Number } \\
\text { of crop } \\
\text { isolates, } \\
\text { units }\end{array}$ & $\begin{array}{c}\text { Growth } \\
\text { retardation, } \\
\mathbf{m m} \\
\text { (Xavg } \pm \Delta \text { ) }\end{array}$ & $\begin{array}{c}\text { Sensitivit } \\
\mathbf{y}, \mathbf{u n i t s}\end{array}$ & $\begin{array}{c}\text { Isolate } \\
\text { sensitivity } \\
\mathbf{\%}\end{array}$ \\
\hline 1 & Proteus vulgaris & 6 & $23.27 \pm 1.85$ & 3 & 50.0 \\
\hline 2 & Staphylococcus aureus & 8 & $21.62 \pm 1.76$ & 5 & 62.5 \\
\hline 3 & Streptococcus faecium & 4 & $22.83 \pm 1.25$ & 2 & 100.0 \\
\hline 4 & Escherichia coli & 12 & $26.11 \pm 2.11$ & 12 & 100 \\
\hline 5 & Citrobacter freundii & 1 & $27.21 \pm 2.12$ & 1 & 100 \\
\hline 6 & $\begin{array}{l}\text { Staphylococcus } \\
\text { pyogenes }\end{array}$ & 15 & $19.13 \pm 1.44$ & 10 & 66.67 \\
\hline
\end{tabular}

Table 2. The results of the sensitivity of the microbiome of the contents of the uterus in acute purulent-catarrhal endometritis of cows to the drug Enroflon.

\begin{tabular}{|c|l|c|c|c|c|}
\hline $\begin{array}{l}\text { Ser. } \\
\text { No. }\end{array}$ & Microbiome & $\begin{array}{l}\text { Number } \\
\text { of crop } \\
\text { isolates, } \\
\text { units }\end{array}$ & $\begin{array}{l}\text { Growth } \\
\text { retardation, } \\
\mathbf{m m} \\
\text { (Xavg } \pm \Delta \text { ) }\end{array}$ & $\begin{array}{l}\text { Sensitivit } \\
\text { y, units }\end{array}$ & $\begin{array}{l}\text { Isolate } \\
\text { sensitivity } \\
\mathbf{\%}\end{array}$ \\
\hline 1 & Proteus vulgaris & 3 & $21.15 \pm 0.62$ & 3 & 100.0 \\
\hline 2 & Staphylococcus aureus & 12 & $23.17 \pm 1.79$ & 7 & 58.33 \\
\hline 3 & Streptococcus faecium & 4 & $25.16 \pm 1.36$ & 4 & 100.0 \\
\hline 4 & Escherichia coli & 18 & $26.33 \pm 1.65$ & 9 & 50 \\
\hline 5 & Citrobacter freundii & 2 & $20.65 \pm 2.03$ & 2 & 100 \\
\hline 6 & $\begin{array}{l}\text { Staphylococcus } \\
\text { pyogenes }\end{array}$ & 12 & $17.22 \pm 0.78$ & 9 & 75.0 \\
\hline
\end{tabular}

Among all the tested drugs, the highest growth inhibition zone for most isolated microbiome isolates was observed in the Mitrec preparation: the growth inhibition zone in Proteus vulgaris was $28.22 \pm 2.37 \mathrm{~mm}$, Staphylococcus aureus - $26.34 \pm 1.34 \mathrm{~mm}$, Streptococcus faecium - $33.0 \pm 2.13 \mathrm{~mm}$, Escherichia coli - $25.52 \pm 1.55 \mathrm{~mm}$, Citrobacter freundii - $21.4 \pm 0.00 \mathrm{~mm}$, Staphylococcus pyogenes - $19.09 \pm 0.66 \mathrm{~mm}$.

Table 3. The results of the sensitivity of the microbiome of the contents of the uterus in acute purulent catarrhal endometritis of cows to the preparation Mitrec.

\begin{tabular}{|c|l|c|c|c|c|}
\hline $\begin{array}{c}\text { Ser. } \\
\text { No. }\end{array}$ & \multicolumn{1}{|c|}{$\begin{array}{c}\text { Number } \\
\text { of crop } \\
\text { isolates, } \\
\text { units }\end{array}$} & $\begin{array}{c}\text { Growth } \\
\text { retardation, } \\
\mathrm{mm} \\
(\text { Xavg } \pm \Delta)\end{array}$ & $\begin{array}{c}\text { Sensiti } \\
\text { vity, } \\
\text { units }\end{array}$ & $\begin{array}{c}\text { Sensiti } \\
\text { vity of } \\
\text { isolate } \\
\mathrm{s}, \%\end{array}$ \\
\hline 1 & Proteus vulgaris & 9 & $28.22 \pm 2.37$ & 9 & 100 \\
\hline 2 & Staphylococcus aureus & 5 & $26.34 \pm 1.34$ & 5 & 100 \\
\hline 3 & Streptococcus faecium & & $33.0 \pm 2.13$ & 2 & 100 \\
\hline 4 & Escherichia coli & 20 & $25.52 \pm 1.55$ & 14 & 70.0 \\
\hline 5 & Citrobacter freundii & 3 & $21.4 \pm 0.00$ & 3 & 100 \\
\hline 6 & Staphylococcus pyogenes & 18 & $19.09 \pm 0.66$ & 15 & 83.33 \\
\hline
\end{tabular}

In addition, the highest percentage of isolates sensitive to mitrec was noted as compared to geomycin and enroflon. 
The most obvious features of the sensitivity of the microflora of the uterus of cows to various drugs are shown in Figure 1.

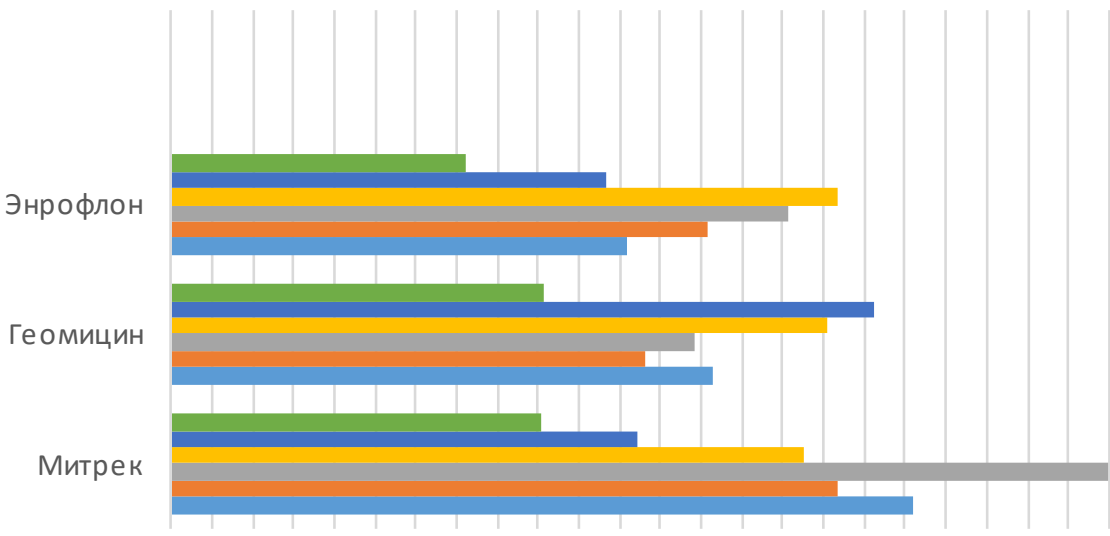

101112131415161718192021222324252627282930313233

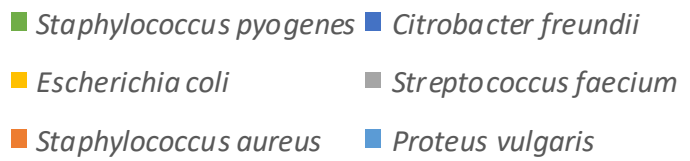

Fig. 1. The results of the sensitivity of the microbiome of the contents of the uterus in acute catarrhalpurulent endometritis of cows to the drugs Mitrec, Geomycin, Enroflon.

Based on the conducted microbiological studies, it can be concluded that the microflora of the contents of the uterus of cows with postpartum acute catarrhal - purulent endometritis is represented by: Streptococcus faecium, Staphylococcus aureus, Escherichia coli, Citrobacter freundii, Streptococcus pyogenes, Proteus vulgaris in cows it was established to the preparation mitrec, which served as the basis for clinical trials of Mitrec ${ }^{\circledR}$ on the cows with postpartum acute purulent-catarrhal endometritis.

Experimental studies have shown that after use of Enroflor ${ }^{\circledR}$, Geomicini ${ }^{\circledR} \mathrm{F}$ and Mitrec ${ }^{\circledR}$ for the treatment of cows with acute postpartum catarrhal-purulent endometritis, clinical recovery within 10 days of therapy occurred only after use of Enroflor ${ }^{\circledR}$ and Mitrec ${ }^{\circledR}$. After using Geomicini ${ }^{\circledR}$ F preparation, clinical recovery was achieved in $91.67 \%$ of the animals (Table 4).

Table 4. Results of treatment of cows with postpartum acute catarrhal-purulent endometritis within 10 days of treatment $(n=12)$.

\begin{tabular}{|l|c|c|c|}
\hline \multirow{2}{*}{ Treatment method } & \multicolumn{2}{|c|}{ Recovered } & Recovery time \\
\cline { 2 - 4 } & heads & \% & days \\
\hline Enroflor ${ }^{\circledR}$ & 12 & 100 & $7.52 \pm 0.19$ \\
\hline Geomicini $^{\circledR} \mathrm{F}$ & 11 & 91.67 & $8.18 \pm 0.31$ \\
\hline Mitrec $^{\circledR}$ & 12 & 100 & $8.35 \pm 0.23$ \\
\hline
\end{tabular}


Table 5. The results of the manifestation of sexual cyclicity in cows for 90 days of observation $(n=$ 12).

\begin{tabular}{|l|c|c|c|c|c|c|}
\hline \multirow{3}{*}{ Treatment method } & \multicolumn{9}{|c|}{ Sexual cycles } \\
\cline { 2 - 7 } & \multicolumn{2}{|c|}{$\mathbf{1}$} & \multicolumn{2}{|c|}{$\mathbf{2}$} & \multicolumn{2}{|c|}{$\mathbf{3}$} \\
\cline { 2 - 7 } & heads & $\mathbf{\%}$ & heads & $\mathbf{\%}$ & heads & \% \\
\hline Enroflor ${ }^{\circledR}$ & 12 & 100 & 7 & 58.33 & 5 & 41.67 \\
\hline Geomicini $^{\circledR} \mathrm{F}$ & 12 & 100 & 8 & 66.67 & 6 & 50.0 \\
\hline Mitrec $^{\circledR}$ & 12 & 100 & 6 & 50.0 & 2 & 16.67 \\
\hline
\end{tabular}

Table 6. The results of cow fertilization after treatment with various methods for 90 days of observation $(\mathrm{n}=12)$.

\begin{tabular}{|l|c|c|c|}
\hline \multirow{2}{*}{ Treatment method } & \multicolumn{2}{|c|}{ Total fertilized } & \multirow{2}{*}{$\begin{array}{c}\text { Index } \\
\text { of insemination }\end{array}$} \\
\cline { 2 - 3 } & heads & \% & 2.0 \\
\hline Enroflor ${ }^{\circledR}$ & 11 & 91.67 & 2.17 \\
\hline Geomicini $^{\circledR} \mathrm{F}$ & 10 & 83.33 & 1.67 \\
\hline Mitrec $^{\circledR}$ & 12 & 100 & \\
\hline
\end{tabular}

Fertility was somewhat lower from use of Enroflon ${ }^{\circledR}$ (Table 7).

Table 7. Results of cows' conception by sexual cycles for 90 days of observations $(\mathrm{n}=12)$.

\begin{tabular}{|l|c|c|c|c|c|c|}
\hline \multirow{2}{*}{$\begin{array}{c}\text { Method } \\
\text { of treatment }\end{array}$} & \multicolumn{6}{|c|}{ Fertilized by sexual cycles } \\
\cline { 2 - 7 } & \multicolumn{2}{|c|}{$\mathbf{1}$} & \multicolumn{2}{|c|}{$\mathbf{2}$} & \multicolumn{2}{|c|}{$\mathbf{3}$} \\
\cline { 2 - 7 } & heads & $\mathbf{\%}$ & heads & \% & heads & \% \\
\hline Enroflor ${ }^{\circledR}$ & 5 & 41.67 & 3 & 25.0 & 3 & 25.0 \\
\hline Geomicini $^{\circledR} \mathrm{F}$ & 4 & 33.33 & 3 & 25.0 & 2 & 16.67 \\
\hline Mitrec $^{\circledR}$ & 6 & 50.0 & 5 & 41.67 & 1 & 8.33 \\
\hline
\end{tabular}

\section{Discussion}

The dynamics of the recovery of cows in the experimental groups of cows with various preparations was characterized first by a decrease and then by a complete cessation of exudate after 3-4 days, followed by a decrease in the size of the uterus. Within palpation, by the 8-10th day, the horns of the uterus had almost the same size, a clearly pronounced interhorn groove.

It shall be noted that faster clinical recovery and uterine involution occurred in the experimental group of cows treated with Enroflor ${ }^{\circledR}$. The recovery period was 1.19 days shorter than in the animals of the second and third experimental groups.

Sexual cyclicity recovery for 90 days of observation occurred in animals of all experimental groups (Table 5).

After treatment of cows with Enroflor ${ }^{\circledR}$ fertilization occurred in $100 \%$ of animals with an insemination index of 1.56 (Table 6).

Fertility of cows after treatment with Geomicini ${ }^{\circledR} \mathrm{F}$ was $88.88 \%$ with an insemination index of 2.12 .

Treatment of cows with Mitrec ${ }^{\circledR}$ proved to be the most effective. Fertilization was higher compared to Enroflor ${ }^{\circledR}$ by $8.33 \%$, and Geomicini ${ }^{\circledR}$ F -17, $67 \%$.

From the analysis of the results of insemination of cows by sexual cycles, it can be seen that the fertility in the first and second sexual cycles, which are decisive in the artificial insemination of females, was quite high in cows that were treated with Mitrec $^{\circledR}$. 


\section{Conclusion}

The highest therapeutic efficacy in the treatment of cows with acute catarrhal - purulent

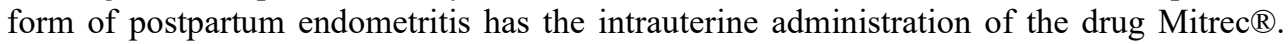
After the intrauterine application of Mitrec ${ }^{\circledR}$, all animals show recovery of sexual cyclicity and high fertility after artificial insemination. An important distinguishing feature of this drug in the treatment of endometritis in cows is the minimum waiting time for milk, which does not exceed 1 day.

\section{References}

1. I. M. Sheldon, J. G. Cronin, G. D. Healey, C. Gabler, W. Heuwieser, D. Streyl, Reproduction, 148 (2014)

2. K. S. Devender, G. N. Purohit, Int. J.Curr.Microbiol App.Sci, 8, 5 (2019)

3. S.J. LeBlanc, T.F. Duffield, K.E. Leslie, K.G. Bateman, G.P. Keefe, J.S. Walton, J. Dairy Sci, 85 (2002)

4. A.M. Semyvolos, I.Y. Pankov, J. of Saratov State Agrarian University named after N.I. Vavilov, 5, 5 (2017)

5. А. М. Семиволос, В.А. Агольцов, И. Ю. Панков, Научная жизнь, 2 (2018)

6. A. Semivolos, V. Agoltsov, O. Popova, T. Rodionova, I. Pankov, N. Solotova, IJPSR, 10, 10 (2019)

7. R. Zobel, S. Tkalčić, Reprod Domest Anim, 48, 1 (2013)

8. M.W. De Boer, S.J. LeBlanc, J. Dubuc, S. Meier, W. Heuwieser, J Dairy Science, 97 (2014)

9. A. Kadivar, M.R. Ahmadi, M. Vatankhah, Trop Anim Health Prod, 46 (2014)

10. I. Sannmann, W. Heuwieser, J. Dairy Sci., 98 (2014)

11. I. M. Sheldon, Anim. Reprod., 14, 3 (2017)

12. M.L. Bicalho, S. Lima, C.H. Higgins, V.S. Machado, F.S. Lima, R.C. Bicalho, J. Dairy Sci., 100 (2017)

13. C.C. Karstrup, J.S. Agerholm, T.K. Jensen, L.R. Swaro, K. Klitgaard, E.L. Rasmussen, Theriogenology, 92 (2017)

14. C.J. Yeoman, S.L. Ishaq, E. Bichi, S.K. Olivo, J. Lowe, B.M. Aldridg, Sci. Rep., 8 (2018)

15. I.M. Sheldon, J.G. Cronin, G.D. Healey, C. Gabler, W. Heuwieser, D. Streyl, Reproduction, 148 (2014)

16. C.C. Karstrup, J.S. Agerholm, T.K. Jensen, L.R. Swaro, K. Klitgaard, E.L. Rasmussen, Theriogenology, 92 (2017)

17. S.H. Cheong, O.G. Sa Filho, V.A. Absalon-Medina, S.H. Pelton, W.R. Butler, R.O. Gilbert, Biol. Reprod, 94 (2016)

18. A. Derakhshandeh, S.M. Aghamiri, M.R. Ahmadi, A. Mirzaei, Vet. Sci. Dev., 5 (2015)

19. R. Ferris, Rev. Bras. Reprod. Anim. Belo Horizonte, 41, 1 (2017)

20. H.B. Wodaje, T.A. Mekuria, Adv. Biol. Res, 10, 4 (2016)

21. J.J. Bromfield, J.E. Santos, J. Block, R.S. Williams, I.M. Sheldon, J. Anim Sci, 93 (2015) 
22. M. L. Bicalho, V. S. Machado, C. H. Higgins, F.S. Lima, R.C. Bicalho, J. Dairy Sci, 100 (2017)

23. M.R. Ahmadi, M. Haghkhah, A. Derakhshandeh, S.M. Aghamiri, A. Mirzaei, S. Nazifi, M. Makki, Theriogenol. Insight, 5, 2 (2015)

24. L.L. Healy, J.G. Cronin, I.M. Sheldon, Biol Reprod, 92 (2015)

25. S.K. Kvidera, E.A. Horst, M. Abuajamieh, E.J. Mayorga, M.V. Fernandez, L.H. Baumgard, J. Dairy Sci., 100 (2017)

26. S.G. Moore, A. C. Ericsson, S.E. Poock, P. Melendez, M.C. Lucy, J. Dairy Sci., 100 (2017)

27. P.G. Noleto, J.P. Saut, I.M. Sheld, J. Dairy Sci., 100 (2017)

28. M.L. Turner, J.G. Cronin, P.G. Noleto, I.M. Sheldon, PLOS One, 11 (2016)

29. J.J. Bromfield, J.E. Santos, J. Block, R.S. Williams, I.M. Sheldon, J. Anim Sci, 93 (2015)

30. S.H. Cheong, O.G. Sa Filho, V.A. Absalon-Medina, S.H. Pelton, W.R. Butler, R.O. Gilbert, Biol Reprod, 94, 18 (2016)

31. P. Haimerl, W. Heuwieser, J. Dairy Sci., 97 (2014)

32. J.R. Chenault, J.F. McAllister, S.T. Chester, V.J. Vandosemple, K.J. Poppe, F.M. Dame, E.J. Robb, J. Am. Vet. Med. Assoc, 224 (2004)

33. A. Pécsi, J. Földi, J. Szabó, P. Nagy, M. Kulcsár, Magy Állatorv Lapja, 129 (2007)

34. K. Königsson, H. Gustafsson, A. Gunnarsson, H. Kindahl, Reprod Domest Anim, 36 (2001)

35. C.L. McLaughlin, E.P. Stanisiewski, C.A. Risco, J.E. Santos, G.E. Dahl, Theriogenology, 79 (2013)

36. C.A. Risco, R.S. Youngquist, M. Shore, Current therapy in large animal theriogenology (Elsevier Inc., 2007)

37. D. Duricic, M. Lipar, M. Samardzija,Vet Arhiv, 84 (2014)

38. M. Samardzija, H. Valpotic, D. Đuricic, O. Szenci, Magy Állatorv Lapja, 137 (2015)

39. M.R. Ahmadi, A. Hosseini, H.R. Gheisari, M. Yavari1, Asian Pac. J. Trop. Dis. (2014)

40. R. Armengo, L. Fraile, Theriogenology, 83 (2015)

41. T.A. Brick, G.M. Schuenemann, S. Bas, J.B. Daniels, C.R. Pinto, J. Dairy Sci., 95 (2012) 